\title{
Nomenclatural notes on Cruciferae
}

\author{
D. A. German ${ }^{1,2}$ \\ ${ }^{1}$ South-Siberian Botanical Garden, Altai State University, Lenina Ave., 61, Barnaul, 656049, Russian Federation \\ ${ }^{2}$ Department of Biodiversity and Plant Systematics, Centre for Organismal Studies, Heidelberg University, \\ Im Neuenheimer Feld 345; Heidelberg, D-69120, Germany \\ E-mail: oreoloma@rambler.ru
}

Keywords: Arabidopsis, Brassicaceae, Dvorakia, Erophila, Eunomia, new combination, Noccaea, Peltariopsis, Pseudocamelina, taxonomy, typification, validation.

Summary. A generic name Dvorakia and combinations Arabidopsis amurensis, A. media, A. multijuga, A. septentrionalis, Dvorakia alaica, D. alyssifolia, Erophila acutidentata, E. aquisgranensis, E. kohlscheidensis, and E. strigosula are validated. Places of valid publication and (except for the first combination) authorship for Erysimum krynitzkii, Eunomia bourgaei, E. rubescens, Pseudocamelina aphragmodes, P. campylopoda, and Thlaspi hastulatum are corrected. For Pseudocamelina and Peltariopsis, information on the types is clarified. Some further minor nomenclatural items are commented.

\section{Номенклатурные заметки о крестоцветных (Cruciferae)}

\author{
Д. А. Герман ${ }^{1,2}$ \\ ${ }^{1}$ Южно-Сибирский ботанический сад, Алтайский государственный университет, \\ просп. Ленина, 61, г. Барнаул, 656049, Россия \\ ${ }^{2}$ Кафедра биоразнообразия и систематики растений, Центр исследований организмов, Гейдельбергский университет, \\ Им Нойенхаймер Фельд, 345, Гейдельберг, D-69120, Германия
}

Ключевые слова: действительное обнародование, новая комбинация, систематика, типификация, Arabidopsis, Brassicaceae, Dvorakia, Erophila, Eunomia, Noccaea, Peltariopsis, Pseudocamelina.

Аннотация. Обнародовано родовое название Dvorakia, а также комбинации Arabidopsis amurensis, A. media, A. multijuga, A. septentrionalis, Dvorakia alaica, D. alyssifolia, Erophila acutidentata, E. aquisgranensis, E. kohlscheidensis и E. strigosula. Для Erysimum krynitzkii, Eunomia bourgaei, E. rubescens, Pseudocamelina aphragmodes, $P$. campylopoda и Thlaspi hastulatum уточнено место действительного обнародования и (за исключением E. krynitzkii) авторство, для Pseudocamelina и Peltariopsis - информация о типе. Приведены комментарии по некоторым другим мелким номенклатурным вопросам.

Further studies on systematics of Cruciferae resulted in some nomenclatural findings and actions presented and commented below.

\section{A new name and combinations}

Arabidopsis multijuga (Borbás), comb. nov. $\equiv$ Arabis multijuga Borbás, 1877, Term-Tud. Közl. 9:
46; id., 1878, Linnaea 41(7): 604. $\equiv$ Arabis arenosa subsp. multijuga (Borbás) Kulcz., 1927, in Szafer, Fl. Polska 3: 162. $\equiv$ Cardaminopsis multijuga (Borbás) Czer., 1981, Pl. Vasc. URSS: 127.

= Arabidopsis arenosa subsp. borbasii (Zapał.) O'Kane et Al-Shehbaz, 1997, Novon 7(3): 325. 三Arabis arenosa subsp. borbasii Zapał., 1912, Rozpr. Wydz. Mat.-Przyr. Acad. Umiejetn., Dzial 
B, Nauki Biol. 52: 31. E Cardaminopsis arenosa subsp. borbasii (Zapał.) Pawł. ex H. Scholz, 1962, Willdenowia 3(1): 139. $\equiv$ C. borbasii (Zapał.) H. E. Hess, Landolt et R. Hirzel, 1972, F1. Schweiz 3: 778. 三Arabidopsis borbasii (Zapał.) A. P. Iljinsk., 2007, Ecofl. Ukraine 5: 65.

There is no consensus among authors regarding the status of the considered plant which is treated either as a subspecies of Arabidopsis arenosa (L.) Lawalrée (e. g., Al-Shehbaz, O’Kane, 2002; Marhold, 2011; Danihelka et al., 2012; Buttler et al., 2018) or, less commonly, as a distinct species (e. g., Iljinska in Iljinska et al., 2007; Dorofeyev, 2012a) though it is generally agreed that the above two heterotypic sets of names belong to the same entity. As follows from the above synonymy [Al-Shehbaz, O'Kane (2002) can be consulted for further names involved], under such concept the final epithet "borbasii" has priority only at the rank of subspecies while at the species level, as accepted here, "multijuga" must be adopted.

\section{North Asian Arabidopsis lyrata grex}

During last two decades, multiple and various evidences (e. g., Schmickl et al., 2008, 2010; Shimizu-Inatsugi et al., 2009; Hohmann et al., 2014; Novikova et al., 2016; etc.) showing that the broad concept (O'Kane, Al-Shehbaz, 1997; Al-Shehbaz, O'Kane, 2002) of several polymorphic Arabidopsis (DC.) Heynh. species somewhat simplifies the situation became available accompanied by increasing number of recognized (chiefly reinstated) species and subspecies (Dorofeyev, 2002; Shimizu et al., 2005; Kolník, Marhold, 2006; Iljinska et al., 2007; Kadota, 2007; Elven, Murray, 2008; summarized by Koch, 2019). Nomenclaturally, the most critical situation is being observed within A. lyrata (L.) O'Kane et Al-Shehbaz complex where, due to the lack of appropriate names, the same epithet "petraea" is used at different ranks in simultaneously applied combinations, viz. A. lyrata subsp. petraea (L.) O'Kane et Al-Shehbaz vs. A. petraea subsp. septentrionalis (N. Busch) Elven et D. F. Murray and A. petraea subsp. umbrosa ("Turcz. ex Steud.") Elven et D. F. Murray. With currently available phylogenetic data (Hohmann et al., 2014; Novikova et al., 2016), there are two options of solving this problem, also mentioned by Elven and Murray (1. c.), namely recognizing relevant entities at species or subspecies level, but then, in contrast to the latter authors' approach, under $A$. lyrata, as informally suggested by Koch (1. c.). In this case, however, it would need to be done not only for the morphologically poorly separable North Asian entities, but also for the most readily distinguishable $A$. arenicola (Richardson) Al-Shehbaz, Elven, D. F. Murray et Warwick, totally accepted as "good" species, reproductively isolated from of $A$. lyrata s. str. (Hohmann et al., 1. c; Koch, 1. c.) but genetically closest to it. Because of this and having in mind relevant commens by Elven and Murray (1. c.) as well as the viewpoint of Yurtsev et al. (2010), an alternative approach is applied here. Although other taxonomic decisions are well predictable in A. lyrata complex, the presented nomenclatural novations enable use of names in agreement with ICN when splitting concept is adopted.

Arabidopsis amurensis (N. Busch), comb. nov. $\equiv$ Arabis amurensis N. Busch, 1922, Notul. Syst. Herb. Hort. Bot. Petrop. 3, 3-4: 12. 三 Cardaminopsis amurensis (N. Busch) O. E. Schulz, 1936, in Engler \& Prantl, Nat. Pflanzenfam., ed. 2, 17B: 541.

Unlike the other two taxa below, A. amurensis was not subjected to molecular studies yet. It is given the same rank since its morphological distinction from the other two similarly recognized entities is comparable to that among them.

Arabidopsis media (N. Busch), comb. nov. $\equiv$ Arabis media N. Busch, 1922, Notul. Syst. Herb. Hort. Bot. Petrop. 3, 3-4: 11. 三 Cardaminopsis media (N. Busch) O. E. Schulz, 1936, in Engler \& Prantl, Nat. Pflanzenfam., ed. 2, 17B: 541. $\equiv$ C. petraea subsp. media (N. Busch) Hämet-Ahti, 1970, Ann. Bot. Fenn. 7: 293.

= Arabis umbrosa Turcz. ex Ledeb., 1841, Fl. Ross. 1: 120, non Crantz, 1762. E Arabis petraea subsp. umbrosa Tolm. 1975, F1. Arct. URSS 7: 97. $\equiv$ "C. petraea subsp. umbrosa (Turcz.)" Peschkova, 1979, F1. Sib. Centr. 1: 396, comb. inval. (Art. 41.5) $\equiv$ C. umbrosa (Tolm.) Czer., 1981, P1. Vasc. URSS: 127. $\equiv$ Arabidopsis petraea subsp. umbrosa (Tolm.) Elven et D. F. Murray, 2008, J. Bot. Res. Inst. Texas 2(1): 439.

Yet untypified Arabis ambigua DC., the oldest name potentially applicable to this species, is not listed here because it also includes elements (p. max. p.) of what is currently known as Arabidopsis kamchatica (Fisch. ex DC.) K. Shimizu et Kudoh (Busch, 1922, 1926, as Arabis kamchatica (Fisch. ex DC.) Ledeb.; Tolmaczev, 1975, as Arabis lyrata subsp. kamchatica (Fisch. ex DC.) Hult.; Shimizu et al., 2005) over which it has priority as well. Because of this heterogeneity since the treatment of Busch (1922, 1926) Arabis ambigua is informally rejected 
and might indeed be a candidate for rejection. At the same time, being generally out of use even as a basionym (varietal level disregarding), it causes no threats at the rank of subspecies where other problems nevertheless exist. In particular, due to priority of the final epithet "media", established by HämetAhti (1970), there is no appropriate name currently available in Arabidopsis for treating this taxon as a subspecies as done by Elven and Murray (1. c.) and followed by some others. The hitherto used combination Arabidopsis petraea subsp. umbrosa, otherwise invalid under ICN Art. 41.7 (Turland et al., 2018), is still validly published due to listing in synonymy, with full and direct reference, of a factual basionym, Arabis petraea subsp. umbrosa, but, again, it is anyway just a potential synonym of any subspecific combination based on A. media.

Additional question is whether Arabis media and Arabis umbrosa Turcz. ex Ledeb. are necessarily homotypic as recently treated by the typifying author (Dorofeyev, 2018: 289) which would mean illegitimacy of both Arabis petraea subsp. umbrosa and Arabidopsis petraea subsp. umbrosa under Art. 52.1 caused by the precedence of Arabis petraea subsp. media. This is apparently not so since Art. 6.13 seems to be applicable for Arabis media, providing a choice of making it either (1) a replacement name or (2) the name of a new taxon. Such choice is not obvious as Busch (1922: 14), despite claiming that "the volume of his [Turczaninow's] A. umbrosa does not correspond the delimitation of my A. media", in fact applied his binominal to the same entity, just with much more abundant material at hand than Turczaninow had, which favours the first option. However, alternative choice has been implicitly done by Dorofeyev (2017: 129) who lectotypified $A$. media by the specimen [and gathering] other than that by which $A$. umbrosa was typified (Dorofeyev, 2018). Hence, the two names are heterotypic by typification and none of the concerned subspecific combinations is illegitimate.

Arabidopsis septentrionalis (N. Busch), comb. nov. $\equiv$ Arabis septentrionalis N. Busch, 1922, Notul. Syst. Herb. Hort. Bot. Petrop. 3, 3-4: 10. झArabis petraea subsp. septentrionalis (N. Busch) Tolm., 1931, Trav. Muz. Bot. (Leningrad) 23: 204. $\equiv$ Cardaminopsis septentrionalis (N. Busch) O. E. Schulz, 1936, in Engler \& Prantl, Nat. Pflanzenfam., ed. 2, 17B: 541. $\equiv$ Arabidopsis petraea subsp. septentrionalis (N. Busch) Elven et D. F. Murray, 2008, J. Bot. Res. Inst. Texas 2(1): 438.
Dvorakia, gen. nov. - Promicrantha Dvořák, 1972, Folia Fac. Sci. Nat. Univ. Purk. Brun., Biol. 13, 4: 55, nom. inval. (Art. 40.1).

Typus: D. alyssifolia

Dvorakia alaica (Korsh.), comb. nov. $\equiv$ Matthiola albicaulis var. alaica Korsh., 1898, Bull. Acad. Sci. Pétersb. 9(5): 407. EIskandera alaica (Korsh.) Botsch. et Vved., 1955, Fl. Uzbekist. 3: 155, in adnot. $\equiv$ "Promicrantha alaica (Korsh.)" Dvořák, 1972, Folia Fac. Sci. Nat. Univ. Purk. Brun., Biol. 13, 4: 59, comb. inval. (Art. 35.1).

Dvorakia alyssifolia (DC.), comb. nov. $\equiv$ Hesperis alyssifolia DC., 1821, Reg. Veg. Syst. Nat. 2: 447. $\equiv$ Matthiola alyssifolia (DC.) Bornm., 1936, Repert. Spec. Nov. Regni Veg. 39: 80. इ"Promicrantha alyssifolia (DC.)" Dvořák, 1972, Folia Fac. Sci. Nat. Univ. Purk. Brun., Biol. 13, 4: 59, comb. inval. (Art. 35.1).

F. Dvořák (1921-2016) proposed five new generic names in Cruciferae, two of which, "Alaida" and "Promicrantha", were not validly published, both times for the reason of lacking the type indication, neither in the original works (Dvořák, 1971, 1972) nor elsewhere later [commented by German (2012) and Jacquemoud (1988), respectively]. While for the prior intended genus no good morphological ground justifying its segregation from Dontostemon Andrz. ex. C. A. Mey. was found (Al-Shehbaz, Ohba, 2000) and molecular phylogeny (e. g., German et al., 2009; Friesen et al., 2016) entirely supported such a lumping approach, it does not seem to be the case for the latter one, and morphology-based conclusion of Dvořák (1972) turned to be congruent with phylogenetic data (e. g., Khosravi et al., 2009; Koch et al., 2018 [https://brassibase.cos.uni-heidelberg.de/]). The generic name (reads ['dvpra:kıa], simplified ['dvprza:kıa]) proposed herein instead of the invalid original designation commemorates Dvořák's appreciable contribution to the systematics of the Cruciferae during his work on the family in second half of 1960ths - beginning of 1970ths.

Erophila acutidentata (Bomble), comb. nov. $\equiv$ Draba acutidentata Bomble, 2017, Veröff. Bochum. Bot. Vereins 9 (2): 23; id., 2018, Jahrb. Bochum. Bot. Vereins 9: 35.

Erophila aquisgranensis (Bomble), comb. nov. $\equiv$ Draba aquisgranensis Bomble, 2017, Veröff. Bochum. Bot. Vereins 9 (2): 17; id., 2018, Jahrb. Bochum. Bot. Vereins 9: 29. 
Erophila kohlscheidensis (Bomble), comb. nov. $\equiv$ Draba kohlscheidensis Bomble, 2017, Veröff. Bochum. Bot. Vereins 9 (2): 21; id., 2018, Jahrb. Bochum. Bot. Vereins 9: 33.

Erophila strigosula (Bomble), comb. nov. $\equiv$ Draba strigosula Bomble, 2017, Veröff. Bochum. Bot. Vereins 9 (2): 13; id., 2018, Jahrb. Bochum. Bot. Vereins 9: 25.

These four species of E. verna (L.) Chevall. aggr. were described as members of Draba L. (Bomble, 2017,2018 ) which is in agreement with the current trend in taxonomy of this group. However, as noted previously (German, 2016), available phylogenetic data (Jordon-Thaden et al., 2010; Karl, Koch, 2013) admit both approaches, of which keeping Erophila DC. separate looks preferable to me.

\section{Comments on validity, places of validation and authorship of names}

\section{Tr.".}

"Clausia aprica var. trichosepala (Turcz.) Korn.-

An attempt to verify the place of validation of this combination given in some databases (The Plant List, 2013; Tropicos.org ) and also in Flora of China (Zhou et al., 2001) led to a conclusion that it originates from Franchet (1883: 181) who cited in synonymy of Cheiranthus apricus var. trichosepalus (Turcz.) Franch. "Clausia aprica, var., trichosepala, Trotzky, Index sem. Hort. Casan., in adnot.". Kornuch-Trotzky (1839), however, did in any way neither mention the potential basionym, Hesperis trichosepala Turcz., nor relevant publication, but instead briefly commented on Candolle's unnamed var. $\beta$ of H. aprica (Stephan ex Willd.) Poir. characterized by "foliis grossè dentatis" (Candolle, 1821: 453) which apparently was misinterpreted by Franchet as what he named Cheiranthus apricus var. trichosepalus. The closest to validate the combination in Clausia Korn.-Tr. was Fournier (1868: 356) by citing "H. trichosepala Turcz. Dec. pl. chin. 3 = Clausia aprica $l$. c. var.", but this way he only "suggested, but not actually formed" (Greuter, 1985: 213) and, consequently, did not validly publish it (ICN Art. 35.2; Turland et al., 2018). The same is true for such underformed designations as "Clausia aprica var. cretacea", "Parrya humilis", and "P. kotschyi" (Fournier, 1. c.). At the same time, the following three combinations, none of which I could find in any source except for the original publication, were validly published by Fournier in that work:
Conringia renifolia (Boiss. et Hohen.) E. Fourn., 1868, Bull. Soc. Bot. France 13: 356. $\equiv$ Hesperis renifolia Boiss. et Hohen., 1849, Diagn. Pl. Or. Nov., ser. 1, 2(8): 22. $\equiv$ Chalcanthus renifolius (Boiss. et Hohen.) Boiss., 1867, Fl. Or. 1: 212. 三Eutrema renifolium (Boiss. et Hohen.) Al-Shehbaz, G. Q. Hao et J. Q. Liu, 2017, Bot. J. Linn. Soc. 184 (2): 218.

Parrya breviscapa (Boiss.) E. Fourn., 1868, Bull. Soc. Bot. France 13: 353. 三 Hesperis breviscapa Boiss., 1842, Ann. Sci. Nat., Bot. Sér. 2, 17: 67.

Sisymbrium speciosum (Sweet) E. Fourn., 1868, Bull. Soc. Bot. France 13: 356. 三 Hesperis speciosa Sweet, 1832, Brit. Gard., ed. 2, 5: tab. 135. = Dendroarabis fruticulosa (C. A. Mey.) D. A. German et Al-Shehbaz (German, 2014).

Erysimum krynitzkii Bordz. [1931, Bull. Jard. Bot. Kieff 12-13: 127, nom. inval. (Art. 36.1(a)); id.], 1938, in Hill, Index Kew., suppl. 9: 107. $\equiv$ E. gelidum subsp. krynitzkii (Bordz.) V. I. Dorof., 1987, Bot. Zhurn. 72(11): 1541. = E. gelidum Bunge (Polatschek, 2010).

Binominal Erysimum krynitzkii which is universally treated as validly published by Bordzilowski (1931) (conf. IPNI; POWO; The Plant List, 2013; etc.), was indicated in relevant work as "spec. nova [ad interim]" and thus was not validated being not definitely accepted by the author (ICN Art. 36(a), Ex. 6; Turland et al., 2018). The name was overlooked in the Flora of USSR (Busch, 1939) but was included into the Caucasian accounts by Grossheim (1949: 402, 1950: 241) and subsequently considered by Czerepanov (1973: 134). In all these and some later works, conditions of a valid publication are met, though the earliest case is evidently $9^{\text {th }}$ addition to Index Kewensis (Hill, 1938), illustrating one of the kinds of such validations highlighted by Greuter (1985: 213).

Eunomia bourgaei (Boiss.) N. Busch, 1907, Acta Horti Bot. Univ. Imp. Jurjev. 7(4): 221; id., 1908, Fl. Cauc. Crit. 3, 4: 141, 142. $\equiv$ Aethionema bourgaei Boiss., 1867, Fl. Or. 1: 344. $\equiv$ Noccaea bourgaei (Boiss.) D. A. German, 2018, Turczaninowia 21, 1: 181.

Eunomia rubescens (Boiss.) N. Busch, 1907, Acta Horti Bot. Univ. Imp. Jurjev. 7(4): 221; id., 1908, Fl. Cauc. Crit. 3, 4: 141, 142. $\equiv$ Aethionema rubescens Boiss., 1867, Fl. Or. 1: 343. $\equiv$ Noccaea rubescens (Boiss.) F. K. Mey., 1973, Feddes Repert. 84(5-6): 459. $\equiv$ Thlaspi rubescens (Boiss.) Greuter et Burdet, 1983, Willdenowia 13(1): 96. 
The combination Eunomia bourgaei is often considered as being validated by Boissier (1867) (e. g., IPNI; The Plant List, 2013) or not treated as validly published name at all (e. g., Meyer, 2006; Tropicos. org), though none of these options is the case. Apparently, citation "Eunomia bourgaei Boiss." by Busch (1907, 1908) who clearly accepted this and the next combination ("I assign to Eunomia the species Aethionema rubescens Boiss. and Ae. Bourgaei Boiss. that are placed by Boissier in the section Iberidella" [originally in Russian]) constitutes an indirect but unambiguous reference to the basionym [given in the prolologue as "Ae. bourgaei (Boiss. pl. Bourg. exs. sub Eunomiâ)"] meeting the requirements of Art. 41.3 (Turland et al., 2018) and resulted in a validation of relevant name. In a similar way, the combination $E$. rubescens was also inadvertently validated by Busch via the citation "Eunomia rubescens Schott et Ky." representing an indirect reference to the basionym ["Ae. rubescens (Schott et Ky. in Sched. sub Eunomiâ)" (Boissier, 1867)]. Noteworthy, the authorship of Aethionema rubescens is still often given as "Schott et Kotschy ex Boiss." (e. g., Meyer, 2006; Marhold, 2011; Al-Shehbaz, 2014) which is in conflict with Art. 46.3 and should be changed to "Boiss.". Another variant, "(Schott et Kotschy ex Tchih.) Boiss." (e. g., in POWO), is also inacceptable since the implied basionym, "Eunomia rubescens Schott et Kotschy ex Tchih.", is nomen nudum, as directly pointed out by Tchichatscheff (1860: 339) who listed it as a "species nondum descripta". The same is true for "Eunomia rubescens Schott et Kotschy" (see Meyer, 2006: 51).

Pseudocamelina aphragmodes (Boiss.) N. Busch [1928, Journ. Soc. Bot. Russe 13(1-2): 115, nom. prov., Art. 36.1(a)] ex O. E. Schulz, 1936, in Engler, Pflanzenfam. 17B: 559.

It is generally believed (Rechinger, 1968; Esmailbegi et al., 2017; IPNI, etc.) that this combination is published by Busch (1928) along with others validated by him in relevant work. The following evidences prove the contrary. First, Busch (1928: 113) states: "Now I consider it necessary to establish one more new genus - Pseudocamelina, consisting of five species" [originally in Russian, translated and boldfaced here and below by me D. A. G.] which are then enumerated, viz. P. szowitsii (Boiss.) N. Busch, P. camelinae "(Boiss.)" N. Busch, P. glaucophylla (DC.) N. Busch, P. violacea (Boiss.) N. Busch, and P. campylocarpa (Boiss.) N. Busch [Busch's order is kept]. After that he continues: "May be perennial P. aphragmodes (Boiss.)
N. Busch should also be assigned here" (Busch 1928: 115, originally in Russian). Thus, Busch definitely did not include this sixth species into Pseudocamelina (Boiss.) N. Busch but only assumed such possibility, i. e., he did not accept his combination $P$. aphragmodes treating it as provisional and therefore leaving it invalid as determined by ICN Art. 36.1(a) (Turland et al. 2018). As the only argument agaist this conclusion, the characteristics "herbae biennes rarius perennes" in the generic description can be mentioned. Indeed, it looks like an indirect indication of inclusion of $P$. aphragmodes, the only perennial among species treated by Busch, into Pseudocamelina. It is clear, however, that relevant phrase comes from Boissier (1867: 247) as a part of the last sentence of his Cochlearia sect. Pseudocamelina Boiss. validating description incorporated by Busch without any alteration. Hence, it reflects the concept of Boissier, who undoubtedly included C. aphragmodes Boiss. into the section, and represents more a "rudiment" of Boissier's characteristics in Busch's work rather than the latter author's intention. One more argument proving that Busch did not accept this species as a member of Pseudocamelina is his own generic characteristics "petala alba" which is absent from Boissier's sectional description. This fits the fact that five species included by Busch into the genus in question have white flowers (rarely fading violescent) and only P. aphragmodes is clearly violet-flowered. To sum up, it is obvious that the final decision of Busch (1928) was to refrain from inclusion of $C$. aphragmodes to Pseudocamelina and, consequently, failure to validate relevant combination. Conditions of a valid publication were subsequently inadvertently fulfilled in several works, such as Rechinger (1968: 222), Miller (1978: 28), Esmailbegi et al. (2017: 119), Kaffash, Assadi (2017: 643). The first who did it was apparently Schulz (1936) by listing "P. aphragmodes (Boiss.) N. Busch" among representative members of Pseudocamelina thus definitely accepting the name and providing an indirect, but unequivocal reference to its basionym, Cochlearia aphragmodes Boiss.

Pseudocamelina campylopoda (Bornm. et Gauba) O. E. Schulz, 1936, in Engler, Pflanzenfam. 17B: 559.

Nordenstam (1968: 658) highlighted the problem of invalidity of the name "Pseudocamelina campylopoda Bornm. et Gauba" adopted by Rechinger (1968: 221). Relevant combination [based on Cochlearia campylopoda Bornm. et Gauba, 1934, Repert. Spec. Nov. Regni Veg. 36: 339] was sub- 
sequently published by Hadač and Chrtek (1973) and since then is being universally accepted as such. However, here, like in the above case of $P$. aphragmodes, validation was first inadvertently reached by Schulz via the citation "P. campylopoda Bornm. et Gauba 1934" (Schulz, 1936: 559) apparently interpretable as unambiguous reference to the basionym, completed by his note under the treatment of Cochlearia L.: "Cochlearia campylopoda Bornm. et Gauba in Fedde, Repert. XXXVI. 16-25 (1934) 339, siehe Pseudocamelina" (Schulz, 1. c.: 461); hence, Art. 41.3 if not 41.5 (Turland et al., 2018) is also to be applied here.

Thlaspi hastulatum (DC.) Ledeb., 1841, Fl. Ross. 1: 162. $\equiv$ Hutchinsia hastulata DC., 1821, Reg. Veg. Syst. Nat. 2: 388. $\equiv$ Noccaea hastulata (DC.) Steud., 1841, Nomencl. Bot., ed. 2, 2: 196. 三 Noccidium hastulatum (DC.) F. K. Mey., 1973, Feddes Repert. 84(5-6): 456.

There are different ways of how the combination Thlaspi hastulatum is given in nomenclatural citations (e. g., Busch, 1939: 591; Hedge, 1968: 115; Meyer, 2003: 117; Dorofeyev, 2012b: 458) illustrating various interpretations concerning its authorship and validity. Zohary et al. (1980: 55) brought good piece of clarity by implicit noting that Hedge's (1. c.) citation fulfills requirements of a valid publication and were followed by Meyer (1. c.) and German (2018) in ascribing relevant transfer to Hedge. However, a more attentive checking showed that the same nomenclatural action has been done yet by Ledebour (1841).

\section{Comments on generic types}

It also seems reasonable to clarify the data on the type of above-discussed Pseudocamelina as long as respective information is confusing even though only one species, P. glaucophylla, is involved. It is listed as the generic type by Miller (1978: 26), Greuter et al. (1993: 932) and Al-Shehbaz (2012: 945, 2015: 560); according to Rollins (1979: 1428) and Farr, Zijlstra (1996+), the type is not designated; finally, Esmailbegi et al. (2017: 118) reported that lectotype is chosen by Busch in Grossheim (1927: 214). Since there is no type designation in the latter work (ICN Art. 7.11, Ex. 15; Turland et al., 2018), the inadvertent choice of Miller is to be followed. Publication of relevant work shortly before issuing the ING explainably prevented taking this information into consideration by its compilers.

Similarly, and in contrast with ING (Rollins, 1979: 1279) and NCU-3 (Greuter et al., 1993: 831), the generic name Peltariopsis (Boiss.) N. Busch was typified in the same paper by Miller (1978: 32) with P. planisiliqua (Boiss.) N. Busch designated as type [i. e., lectotype] making subsequent deliberate choice (Al-Shehbaz, 2012: 945) superfluous.

\section{Acknowledgements}

Kind sharing of nomenclatural experience and advice on various items by Alexander Nikolaevich Sennikov is sincerely appreciated by the author.

\section{REFERENCES / ЛИTEPATУPA}

Al-Shehbaz I. A. 2012. A generic and tribal synopsis of the Brassicaceae (Cruciferae). Taxon 61(5): 931-954. URL: http://www.jstor.org/stable/41679341

Al-Shehbaz I. A. 2014. A synopsis of the genus Noccaea (Coluteocarpeae, Brassicaceae). Harvard Pap. Bot. 19(1): 25-51. DOI: 10.3100/hpib.v19iss1.2014.n3

Al-Shehbaz I. A. 2015. Brassicaceae. In: Flora of Pan-Himalaya. Ed. D. Y. Hong. Vol. 30. Cambridge University Press, Cambridge; Science Press, Beijing. Pp. 1-595.

Al-Shehbaz I. A., Ohba H. 2000. The status of Dimorphostemon and two new combinations in Dontostemon (Brassicaceae). Novon 10(2): 95-98. DOI: 10.2307/3393002

Al-Shehbaz I. A., O'Kane S. L., Jr. 2002. Taxonomy and phylogeny of Arabidopsis (Brassicaceae). In: The Arabidopsis Book. Eds. C. R. Somerville, E. M. Meyerowitz. American Society of Plant Biologists, Rockville, Maryland. Published online 30 IX 2002. DOI: 10.1199/tab.0001; URL: https:/www.ncbi.nlm.nih.gov/pmc/articles/PMC3243115/

Boissier E. 1867. Flora Orientalis. Vol. 1. Basel \& Genève, H. Georg, XXXIV + 1017 pp. DOI: 10.5962/bhl. title. 20323

Bomble F. W. 2017. Vier neue, kontrastreich gefärbte Arten von Draba subgen. Erophila in Aachen und Umgebung. Veröff. Bochumer Bot. Ver. 9(2): 11-27. URL: http://www.botanik-bochum.de/publ/OVBBV9_2_Bomble_Draba_subgen_Erophila_Aachen.pdf

Bomble F. W. 2018. Vier neue, kontrastreich gefärbte Arten von Draba subgen. Erophila in Aachen und Umgebung. Jahrb. Bochumer Bot. Ver. 9: 23-39. 
Bordzilowski E. I. 1931. De plantis nonnulis armeniacis et dzhawakheticis. 1. Bull. Jard. Bot. Kieff 12-13: 105142 [In Ukrainian]. (Бордзиловський $\boldsymbol{C}$. I. Про деякі вірменьскі й джавахетські рослини. I // Вісник Київського бот. саду, 1931. Вип. 12-13. С. 105-144).

Busch N. 1907. Systematics and botanical geography of Caucasian representatives of the genera Aethionema R. Br. and Eunomia DC. Trudy Bot. Sada Imp. Yur'evsk. Univ. [Acta Horti Bot. Univ. Imp. Jurjev.] 7(4): 218-228 [In Russian]. (Буш Н. Систематика и ботаническая география кавказских представителей родов Aethionema $\mathrm{R}$. Br. и Eunomia DC. // Труды бот. сада имп. Юрьевск. ун-та, 1907. Т. 7, вып. 4. С. 218-228).

Busch N. 1908-1910. Cruciferae, Capparidaceae, Resedaceae, Droseraceae. Rhoedales, Sarraceniales: addenda et corrigenda, index nominum et synonymorum, [introduction]. In: N. Kuznetsov, N. Busch, A. Fomin. Flora caucasica critica. Materialy flory Kavkaza [Materials for the flora of Caucasus]. Part. 3. Iss. 4 (No. 29 and 30).Typography of K. Mattisen, Yuryev, LXXIV + 820 pp. [In Russian]. (Буи H. Cruciferae, Capparidaceae, Resedaceae, Droseraceae. Rhoedales, Sarraceniales: addenda et corrigenda, index nominum et synonymorum, введение // Н. Кузнецов, Н. Буши, A. Фомин. Flora caucasica critica. Материалы для флоры Кавказа. Ч. 3, вып. 4 (вып. 29 и 30). Юрьев: Типография К. Маттисена, 1910. LXXIV + 820 с.).

Busch N. 1922. De conspecies Arabide petraea Lam. in Sibiria et Oriente Extremo. Bot. Mater. Gerb. Glavn. Bot. Sada R.S.F.S.R. [Notul. Syst. Herb. Hort. Bot. Petrop.] 3, 3-4: 9-16 [In Russian]. (Буш Н. А. Цикл географических рас сборного вида Arabis petraea Lam. в Сибири и на Дальнем Востоке // Бот. мат. Герб. Главн. бот. сада РСФСР, 1922. Т. 3, вып. 3-4. С. 9-16).

Busch N. A. 1926. Cruciferae (sheets 26-32). In: Flora Sibiriae et Orientis Extremi [Flora of Siberia and the Far East]. Iss. 4. Ivan Fedorov State Typography, Leningrad. Pp. 393-490. [In Russian]. (Буш Н. A. Cruciferae (листы 26-32) // Флора Сибири и Дальнего Востока. Вып. 4. Л.: Гос. типография им. Ивана Федорова, 1926. С. 393-490).

Busch N. 1928. Sur un nouveau genre de Crucifères. Zurn. Russk. Bot. Obsc. Akad. Nauk SSSR [Journ. Soc. Bot. Russe] 13(1-2): 113-115 [In Russian]. (Буи Н. A. О новом роде крестоцветных // Журн. Русск. бот. об-ва, 1928. T. 13, № 1-2. C. 113-115).

Busch N. A. 1939. Erysimum (Tourn.) L.; Carpoceras Boiss. In: Flora URSS [Flora of USSR]. Vol. 8. Ed. V. L. Komarov. Editio Academiae Scientarum URSS, Moscow \& Leningrad. Pp. 92-127, 637-639; 591-593. [In Russian]. (Буш Н. А. Желтушник - Erysimum (Tourn.) L.; Рогоплодник - Carpoceras Boiss. // Флора CCCР. Т. 8. Под ред. В. Л. Комарова. М.-Л.: Изд-во АН СССР, 1939. С. 92-127, 637-639; 591-593).

Buttler K. P., Thieme M. \& Mitarbeiter. [2018]. Florenliste von Deutschland-Gefäßpflanzen. Version 10. Frankfurt am Main, August 2018. URL: http://www.kp-buttler.de

Candolle A. P. de. 1821. Regni vegetabilis systema naturale. Vol. 2. Socii Treuttel et Würtz, Parisiis [Paris], [II] + $745 \mathrm{pp}$.

Czerepanov S. K. 1973. Additamenta et corrigenda ad "Floram URSS (tomi I-XXX)" [Additions and corrections to the "Flora of USSR (volumes I-XXX)”']. Nauka, Leningrad branch, Leningrad, 668 pp. [In Russian]. (Черепанов $\boldsymbol{C}$. $\boldsymbol{\kappa}$. Свод дополнений и изменений к «Флоре СССР» (тт. I - XXX). Л.: «Наука», Ленингр. отд-е, 1973.668 с.).

Danihelka J., Chrtek J. Jr., Kaplan Z. 2012. Checklist of vascular plants of the Czech Republic. Preslia 84(3): 647-811. URL: http://www.preslia.cz/P123Danihelka.pdf

Dorofeyev V. I. 2002. Cruciferae of European Russia. Turczaninowia 5, 3: 5-114. [In Russian]. (Дорофеев В. И. Крестоцветные (Cruciferae Juss.) Европейской России // Тurczaninowia, 2002. Т. 5, вып. 3. C. 5-114).

Dorofeyev V. I. 2012a. Brassicaceae Burnett (Cruciferae Juss.). In: Conspectus florae Europae orientalis. Ed. N. N. Tzvelev. Vol. 1. KMK Scientific Press, St. Petersburg \& Moscow. Pp. 364-437. [In Russian]. (Дорофеев В. И. Brassicaceae Burnett (Cruciferae Juss.) // Конспект флоры Кавказа. Под ред. Н. Н. Цвелёва. Т. 1. СПб.-М.: Товарищество научных изданий КМК, 2012а. С. 364-437).

Dorofeyev V. I. 2012b. Brassicaceae Burnett, nom. cons., nom. alt. (Cruciferae Juss., nom. cons.). In: Conspectus florae Caucasi. Ed. A. L. Takhtajan. Vol. 3(2). KMK Scientific Press, St. Petersburg \& Moscow. Pp. 371-469. [In Russian]. (Дорофеев В. И. Brassicaceae Burnett, nom. cons., nom. alt. (Cruciferae Juss., nom. cons.) // Конспект флоры Кавказа. Под ред. А. Л. Тахтаджяна. Т. 3(2). СПб.-М.: Товарищество научных изданий КМК, 20126. С. 371-469).

Dorofeyev V. I. 2017. Additions to the type collection of Cruciferae Juss. (Brassicaceae Burnett) of Siberia and Russian Far East kept in Herbarium of V. L. Komarov Botanical Institute (LE). Turczaninowia 20, 1: 127-148 [In Russian]. (Дорофеев В. И. Дополнения к коллекции типов сем. Cruciferae Juss. (Brassicaceae Вurnett) Сибири и российского Дальнего Востока Гербария Ботанического института им. В. Л. Комарова (LE) // Turczaninowia, 2017. Т. 20, вып. 1. C. 127-148). DOI: 10.14258/turczaninowia.20.1.12

Dorofeyev V. I. 2018. Brassicaceae Burnett (Cruciferae Juss.). In: Catalogue of the type specimens of the vascular plants from Siberia and the Russian Far East kept in the Herbarium of the Komarov Botanical Institute. Ed. I. V. Sokolova. Part 2. KMK Scientific Press, Moscow \& St. Petersburg. Pp. 279-365. [In Russian]. (Дорофеев В. И. Brassicaceae Burnett (Cruciferae Juss.) // Каталог типовых образцов сосудистых растений Сибири и российского 
Дальнего Востока, хранящихся в Гербарии Ботанического института им. В. Л. Комарова РАН (LE). Отв. ред. И. В. Соколова. Ч. 2. СПб.-М.: Товарищество научных изданий КМК, 2018. С. 279-365 с.).

Dvoŕák F. 1971. A study on the species Arabis glandulosa Kar. \& Kir. Feddes Repert. 82(6): 421-432. DOI: 10.1002/fedr.19710820604

Dvoŕák F. 1972. Study of the evolutional relationship of the tribe Hesperideae. Folia Fac. Sci. Nat. Univ. Purkynianae Brun., Biol. 13, 4: 1-82.

Elven R., Murray D. F. 2008. New combinations in the Panarctic vascular plant flora. J. Bot. Res. Inst. Texas 2(1): 433-446. URL: https://www.jstor.org/stable/41971656

Esmailbegi Sh., Lysak M. A., Rahiminejad M. R., Mirtadzadini M., Mummenhoff K., Al-Shehbaz I. A. 2017. A taxonomic revision of the genus Pseudocamelina (Brassicaceae, tribe Thlaspideae). Phytotaxa 313(1): 117-129. DOI: 10.11646/phytotaxa.313.1.8

Farr E. R., Zijlstra G. (eds.). 1996+ [updated 24 January 2013]. Index Nominum Genericorum (Plantarum). URL: https://naturalhistory2.si.edu/botany/ing/ (Accessed 20 April 2018).

Fournier E. 1868. ['1866'] Monographie du genre Hesperis. Bull. Soc. Bot. France 13: 326-362.

Franchet M. A. 1883-1884. Plantae Davidianae ex sinarum imperio. Première partie. Plantes de Mongolie du nord et du centre de la Chine. Nouv. Arch. Mus. Hist. Nat., sér. 2, 5: 153-272; 6: 1-126; 7: 55-200.

Friesen N., German D. A., Hurka H., Herden T., Oyuntsetseg B., Neuffer B. 2016. Dated phylogenies and historical biogeography of Dontostemon and Clausia (Brassicaceae) mirror the palaeogeographic history of the Eurasian steppe. J. Biogeogr. 43(4): 738-749. DOI: 10.1111/jbi.12658

German D. A. 2012. Typification of some names in the Cruciferae, mostly from North Asia. Turczaninowia 15, 3: 9-16.

German D. A. 2014. New synonyms and combinations in Eurasian Brassicaceae (Cruciferae). Phytotaxa 173(1): 31-40. DOI: 10.11646/phytotaxa.173.1.2

German D. A. 2016. Taxonomic notes on miscellaneous Cruciferae. Turczaninowia 19, 4: 129-135. DOI: 10.14258/ turczaninowia.19.4.17

German D. A. 2018. On the identity of some endemic SW Asian Cruciferae. I. Thlaspi s. 1. Turczaninowia 21, 1: 180-187. DOI: $10.14258 /$ turczaninowia.21.1.18

German D. A., Friesen N., Neuffer B., Al-Shehbaz I. A., Hurka H. 2009. Contribution to ITS phylogeny of the Brassicaceae, with a special reference to some Asian taxa. Plant Syst. Evol. 283(1): 33-56. DOI: 10.1007/s00606009-0213-5

Greuter W. 1985. 9. The "Index Kewensis" as a source of validation of new species names. In: Med-Checklist notulae bibliographicae, 9 à 13. Ed. H. M. Burdet. Candollea 40(1): 211-213.

Greuter W., Brummit R. K., Farr E., Kilian N., Kirk P. M., Silva P. C. (eds.). 1993. NCU-3. Names in current use for extant plant genera. [Regnum Vegetabile, vol. 129]. Koeltz Scientific Books, Königstein, XXVII + 1464 pp.

Grossheim A. A. 1927. Iter Persicum Primum. Beih. Bot. Centralbl., Abt. 2. 44(2): 199-248.

Grossheim A. A. 1949. Opredelitel rasteniy Kavkaza [Key for plants of Caucasus]. Sovetskaya Nauka, Moscow, 747 pp. [In Russian]. (Гроссгейм A. A. Определитель растений Кавказа. М.: Советская наука, 1949. 747 с.).

Grossheim A. A. 1950. Flora Kavkaza [Flora of Caucasus]. Ed. 2. Vol. 4. Nymphaeaceae - Platanaceae. Publishers of Academy of Sciences of USSR, Moscow \& Leningrad, $311+$ [178] + XXI pp. [In Russian]. (Гроссгейм $\boldsymbol{A}$. $\boldsymbol{A}$. Флора Кавказа. 2-е изд., перераб. и доп. Т. 4. Nymphaeaceae - Platanaceae. М.-Л.: Изд-во АН СССР, $1950.311+$ $[178]+$ XXI c.).

Hadač E., Chrtek J. 1973. A contribution to the Brassicaceae of Iraq. Acta Univ Carol., Biol. 1971(4): 231-265.

Hämet-Ahti L. 1970. A. K. Cajander's vascular plant collection from the Lena River, Siberia, with his ecological and floristic notes. Ann. Bot. Fenn. 7(3): 255-324. URL: https://www.jstor.org/stable/23724659

Hedge I. C. 1968. Lepidieae. In: Flora Iranica. Vol. 57. Ed. K. H. Rechinger. Akademische Druck- u. Verlagsanstalt, Graz. Pp. 63-122.

Hill A. W. 1938. Index Kewensis plantarum phanerogamum. Supplementum nonum. E Prelo Clarendoniano [Clarendon Press], Oxonii [Oxford], 305 pp.

Hohmann N., Schmickl R., Chiang T.-Y., Lučanová M., Kolář F., Marhold K., Koch M. A. 2014. Taming the wild: resolving the gene pools of non-model Arabidopsis lineages. BMC Evol. Biol. 14: 224. DOI: 10.1186/s12862014-0224-X

Iljinska A., Didykh Ya., Burda R., Korotchenko I. 2007. Brassicaceae Burnett (Cruciferae Juss.). In: Ecoflora of Ukraine. Vol. 5. Ed. Ya. Didykh. Phytosociocentre, Kyiv. Pp. 7-538. [In Ukrainian]. (Ільӥнська А. П., Дідух Я. П., Бурда P. I., Коротченко I. A. Brassicaceae Burnett (Cruciferae Juss.) // Екофлора України. Відпов. ред. Я. П. Дідух. Т. 5. Київ: Фітосоціоцентр, 2007. С. 7-538).

[IPNI] The International Plant Names Index. URL: http://www.ipni.org (Accessed 8 June 2019).

Jacquemoud F. 1988. Monographie du genre Sterigmostemum M. Bieb. (Cruciferae - Hesperideae). Boissiera 40: 5-161. 
Jordon-Thaden I., Hase I., Al-Shehbaz I. A., Koch M. A. 2010. Molecular phylogeny and systematics of the genus Draba s. 1. (Brassicaceae) and identification of its closest related genera. Mol. Phylogenet. Evol. 55(2): 524-540. DOI: 10.1016/j.ympev.2010.02.012

Kaffash Sh., Assadi M. 2017. Pseudocamelina (Boiss.) N. Busch. In: Flora of Iran. Vol. 143 (Brassicaceae). Ed. M. Assadi. Ministry of Jihad-e-Agriculture, etc., Tehran. Pp. 636-643. [In Persian].

Kadota Y. 2007. Arabidopsis umezawana (Brassicaceae), a new species from Mt. Rishirizan, Rishiri Island, Hokkaido, Northern Japan. J. Jap. Bot. 82(4): 232-237. URL: http://www.jjbotany.com/pdf/JJB_082_232_237.pdf

Karl R., Koch M. A. 2013. A world-wide perspective on crucifer speciation and evolution: phylogenetics, biogeography and trait evolution in tribe Arabideae. Ann. Bot. 112(6): 983-1001. DOI: 10.1093/aob/mct165.

Khosravi A. R., Mohsenzadeh S., Mummenhoff K. 2009. Phylogenetic relationships of Old World Brassicaceae from Iran based on nuclear ribosomal DNA sequences. Biochem. Syst. Ecol. 37(2): 106-115. DOI: 10.1016/j. bse.2009.01.010

Koch M. A. 2019. The plant model system Arabidopsis set in an evolutionary, systematic, and spatio-temporal context. J. Exp. Bot. 70(1): 55-67. DOI: 10.1093/jxb/ery340

Koch M. A., German D. A., Kiefer M., Franzke A. 2018. Database taxonomics as key to modern plant biology. Trends Plant Sci. 23(1): 4-6. DOI: 10.1016/j.tplants.2017.10.005

Kolník M., Marhold K. 2006. Distribution, chromosome numbers and nomenclature concept of Arabidopsis halleri (Brassicaceae) in the Carpathians. Biologia, Sect. Bot. 61(1): 41-50. DOI: 10.2478/s11756-006-0007-y

Kornuch-Trotzky P. 1839. Delectus seminum ex collectione a. 1839, quae in h. bot. Universitatis Caesarae Casanensis pro commutatione offeruntur. Casani [Kasan], 4 pp.

Ledebour C. F. 1841. Flora Rossica sive enumeratio plantarum in totius imperii rossici provinciis europaeis, asiaticis et americanis hucusque observatarum. Vol. 1. P. 1. Sumptibus librariae E. Schweizerbart, Stuttgartiae, [I]-XVI + [1]-240 pp.

Marhold K. 2011. Brassicaceae. In: Euro+Med: Euro+Med PlantBase - the information resource for Euro-Mediterranean plant diversity. URL: http://ww2.bgbm.org/EuroPlusMed (Accessed 19 September 2018).

Meyer F. K. 2003. Kritische Revision der "Thlaspi"-Arten Europas, Afrikas und Vorderasiens. V. Noccidium F. K. Mey. Haussknechtia 9: 115-124.

Meyer F. K. 2006. Kritische Revision der "Thlaspi"-Arten Europas, Afrikas und Vorderasiens. IX. Noccaea Moench. Haussknechtia 12, Beih.: 1-343.

Miller A. G. 1978. A reassessment of the genus Pseudocamelina. Notes Royal Bot. Gard. Edinburgh 36(1): $23-33$.

Nordenstam B. 1968. K. H. Rechinger: Flora Iranica [review]. Bot. Notiser 121(4): 657-659.

Novikova P. Yu., Hohmann N., Nizhynska V., Tsuchimatsu T., Ali J., Muir G., Guggisberg A., Paape T., Schmid K., Fedorenko O. M., Holm S., Säll T., Schlötterer C., Marhold K., Widmer A., Sese J., Shimizu K. K., Weigel D., Krämer U., Koch M. A., Nordborg M. 2016. Sequencing of the genus Arabidopsis identifies a complex history of nonbifurcating speciation and abundant trans-specific polymorphism. Nat. Genet. 48(9): 1077-1082. DOI: 10.1038/ ng. 3617

O’Kane S. L., Jr., Al-Shehbaz I. A. 1997. A synopsis of Arabidopsis (Brassicaceae). Novon 7(3): 323-327. DOI: $10.2307 / 3391949$

[POWO] Plants of the World online. URL: http://www.plantsoftheworldonline.org/ (Accessed 16 May 2019).

Polatschek A. 2010. Revision der Gattung Erysimum (Cruciferae): Teil 1: Russland, die Nachfolgestaaten der USSR (excl. Georgien, Armenien, Azerbaidzan), China, Indien, Pakistan, Japan und Korea. Ann. Naturhist. Mus. Wien, B 111: 181-275. URL: https://www.zobodat.at/pdf/ANNA_112B_0369-0497.pdf

Rechinger K. H. 1968. Matthioleae. In: Flora Iranica. Vol. 57. Ed. K. H. Rechinger. Academische Druck- u. Verlagsanstalt, Graz. Pp. 219-250.

Rollins R. C. 1979. Peltariopsis (Boissier) N. Busch; Pseudocamelina (Boissier) Busch. In: Index Nominum Genericorum (Plantarum). Eds. E. R. Farr, J. A. Leussink, F. A. Stafleu. Bohn, Scheltema \& Holkema, Utrecht; Junk, The Hague. Pp. 1279, 1428.

Schmickl R., Jorgensen M. H., Brysting A. K., Koch M. A. 2008. Phylogeographic implications for the North American boreal-arctic Arabidopsis lyrata complex. Plant Ecol. Div. 1(2): 245-254. DOI: 10.1080/17550870802349138

Schmickl R., Jorgensen M. H., Brysting A. K., Koch M. A. 2010. The evolutionary history of the Arabidopsis lyrata complex: a hybrid in the amphi-Beringian area closes a large distribution gap and builds up a genetic barrier. BMC Evol. Biol. 10: e98. DOI: 10.1186/1471-2148-10-98

Shimizu K. K., Fujii S., Marhold K., Watanabe K., Kudoh H. 2005. Arabidopsis kamchatica (Fisch. ex DC.) K. Shimizu \& Kudoh and A. kamchatica subsp. kawasakiana (Makino) K. Shimizu \& Kudoh, new combinations. Acta Phytotax. Geobot. 56(2): 163-172. DOI: 10.18942/apg.KJ00004623241

Shimizu-Inatsugi R., Lihová J., Iwanaga H., Kudoh H., Marhold K., Savolainen O., Watanabe K., Yakubov V. V., Shimizu K. K. 2009. The allopolyploid Arabidopsis kamchatica originated from multiple individuals of Arabidopsis lyrata and Arabidopsis halleri. Mol. Ecol. 18(19): 4024-4048. DOI: 10.1111/j.1365-294X.2009.04329.x 
Tchichatscheff P. A. 1860. Asie Mineure: description physique, statistique et archéologique de cette contrée. Troisième partie: Botanique. Vol. 1. Gide, Paris, LVI + 484 pp. DOI: org/10.5962/bhl.title.12040

The Plant List. 2013. Version 1.1. URL: http://www.theplantlist.org (Accessed 16 December 2018)

Tolmaczev A. I. 1975. Arabis L. In: Flora Arctica URSS [Arctic Flora of USSR]. Ed. A. I. Tolmaczev. Vol. 7. Papaveraceae - Cruciferae. Nauka, sectio Leninopoli, Leningrad. Pp. 92-99. [In Russian]. (Толмачёв A. И. Arabis L. Резуха // Арктическая флора СССР. Под ред. А. И. Толмачёва. Вып. 7. Papaveraceae - Cruciferae. Л.: «Наука», Ленингр. отд-е, 1975. С. 92-99).

Tropicos.org. Missouri Botanical Garden. URL: http://www.tropicos.org (accessed 23 December 2018).

Turland N. J., Wiersema J. H., Barrie F. R., Greuter W., Hawksworth D. L., Herendeen P. S., Knapp S., Kusber W.-H., Li D.-Z., Marhold K., May T. W., McNeill J., Monro A. M., Prado J., Price M. J., Smith G. F. 2018. International Code of Nomenclature for algae, fungi, and plants (Shenzhen Code) adopted by the Nineteenth International Botanical Congress Shenzhen, China, July 2017. [Regnum Vegetabile, vol. 159]. Koeltz Scientific Books, Glashütten, 254 pp. DOI: 10.12705/Code.2018

Yurtsev B. A., Koroleva T. M., Petrovsky V. V., Polozova T. G., Zhukova P. G., Katenin A. E. 2010. A checklist of flora of the Chukotkan Tundra. VVM Ltd. Publishing, St. Petersburg, 628 pp. [In Russian]. (Юрцев Б. А., Королёва T. М., Петровский В. В., Полозова Т. Г., Жукова П. Г., Катенин А. Е. Конспект флоры Чукотской тундры. СПб.: ВВМ, 2010. 628 с.).

Zhou T.-Y., Lu L.-L., Yang G., Al-Shehbaz I. A. 2001. Brassicaceae (Cruciferae). In: Flora of China. Vol. 8 (Brassicaceae through Saxifragaceae). Eds. Z.-Y. Wu, P. H. Raven. Science Press, Beijing; Missouri Botanical Garden Press, St. Louis. Pp. 1-193.

Zohary M., Heyn C. C., Heller D. 1980. Conspectus florae orientalis. An annotated catalogue of the flora of the Middle East. Vol. 1. The Israel Academy of Sciences and Humanities, Jerusalem, 107 pp. 